\title{
Evaluation of Demographic and Clinical Characteristics of Patients with Mucopolysaccharidosis
}

\section{Mukopolisakkaridoz Hastalarının Demografik ve Klinik Özelliklerinin Değerlendirilmesi}

\author{
Pelin Teke Kısa', Engin Köse', Merve Ateşoğlu², Nur Arslan¹ \\ ${ }^{1}$ Dokuz Eylül University Faculty of Medicine, Department of Pediatrics, Division of Nutrition and Metabolism, Izmir, Turkey \\ ${ }^{2}$ Dokuz Eylül University Faculty of Medicine, Department of General Pediatrics, Izmir, Turkey
}

\begin{abstract}
Aim: Mucopolysaccharidoses (MPSs) are a group of lysosomal storage disorders caused by the deficiency of spesific lysosomal enzymes required to break down glycosaminoglycans. MPSs should be suspected in a child with coarse facial features, organomegaly, and bone disease (dysostosis multiplex), with central nervous system abnormalities. Early diagnosis and treatment can improve outcomes in MPS. The aim of this study was to evaluate the demographic characteristics and clinical findings of our MPS patients.

Materials and Methods: This is a retrospective study which included 27 MPS patients who were diagnosed and treated in our center.

Results: The mean age of the group was $112.3 \pm 52.5$ months (36-196 months); the mean onset age of symptoms was $40.8 \pm 30.6$ months (4-112 months), and the mean time from symptom onset to diagnosis was $16.3 \pm 21.4$ months (0-80 months). MPS subgroups were Type III in $13(48 \%)$ patients, Type II in seven $(26 \%)$, Type VI in four (15\%), Type I in two (7\%) patients and Type IV in one patient. Nine (33.3\%) patients received enzyme replacement therapy (ERT). The mean duration of ERT was 31.3 21.5 months (9-67 months).

Conclusion: MPS Type III was found to be the most common subgroup in our center. We can speculate that the mean time from symptom onset to diagnosis was found too long for MPS in which early diagnosis improves the prognosis. Increasing awareness of the disease in physicians encountering these patients in different clinics will be an important factor in the early diagnosis of the disease.
\end{abstract}

Keywords: Mucopolysaccharidosis, pediatrics, consanguinity, enzyme replacement therapy

\section{ÖZ}

Amaç: Mukopolisakkaridozlar (MPS) glikozaminoglikanların yıkımında görev alan spesifik lizozomal enzimlerin eksikliği sonucu görülen bir grup lizozomal depo hastalıklarıdır. Kaba yüz, organomegali, kemik hastalığı (disostoz multipleks) ve merkezi sinir sistemi bulguları görülen hastalarda MPS hastalığı akla gelmelidir. MPS hastalığında erken tanı ve tedavi prognozda önemlidir. Bu çalışmanın amacı MPS tanısıyla takip edilen hastalarımııın klinik ve demografik verilerinin araştııımasıdır.

Gereç ve Yöntemler: Bu çalışmada 27 MPS'li hastanın demografik ve klinik özellikleri retrospektif olarak kaydedildi.

Bulgular: Hastaların yaş ortalaması $112,3 \pm 52,5$ ay (36-196 ay), semptomların başlama yaşı ortalama $40,8 \pm 30,6$ ay idi (4-112 ay). Semptom başlangıcından tanıya kadar geçen süre ortalama $16,3 \pm 21,4$ ay idi. Hastaların 13'ü (\%48) MPS Tip III, yedisi (\%26) MPS Tip II, dördü (\%15) MPS Tip VI, ikisi (\%7) MPS Tip I ve biri (\%4) MPS Tip IV tanısı almışlardı. Dokuz $(\% 33,3)$ hastaya enzim replasman tedavisi (ERT) başlandı. Ortalama ERT süresi $31,3 \pm 21,5$ ay idi.

Sonuç: Çalışmamızda en sık görülen MPS alt grubu MPS Tip III olarak bulundu. Çalışmamızda hastaların semptomlarının başlangııından tanı konulmasına kadar geçen süre uzun bulunmuştur. Bu hastalarla farklı kliniklerde karşılaşan hekimlerin hastalık hakkındaki farkındalığının artırıması hastalara daha erken tanı konulmasında önemli bir faktör olacaktır.

Anahtar Kelimeler: Mukopolisakkaridoz, çocuk, akrabalık, enzim replasman tedavisi

\section{Address for Correspondence/Yazısma Adresi}

Pelin Teke KIsa MD, Dokuz Ey/ül University Faculty of Medicine, Department of Pediatrics, Division of Nutrition and Metabolism, Izmir, Turkey

Phone: +90 2324126110 E-mail: pteke@hotmail.com

Received/Geliş tarihi: 19.02.2017 Accepted/Kabul tarihi: 07.03.2017

- Copyright 2017 by Ege University and Ege Children's Foundation

The Journal of Pediatric Research, published by Galenos Yayınevi. 


\section{Introduction}

Mucopolysaccharidoses (MPSs) are lysosomal storage disorders that are characterized by the dysfunction of the lysosomal enzymes involved in the catabolism of glycosaminoglycans (GAGs) due to a genetic mutation and GAG accumulation in the tissues (1). This accumulation differs depending on the deficiency of the specific enzyme (1). Seven types of MPS have been defined. MPS III and MPS IV have two or more subtypes biochemically. MPS I is divided into three subtypes according to the severity of the disease: Hurler syndrome (severe form), Hurler-Scheie syndrome, and Scheie syndrome (mild form) (2). MPS II is also divided into two subtypes as neurological and non-neurological (3). In MPS patients, clinical manifestations including cardiovascular diseases (common and early finding), obstructive type respiratory diseases, auditory impairment, visual problems (corneal clouding, glaucoma, retinal degeneration), and musculoskeletal diseases (short stature, joint stiffness or hyperlaxity, peripheral nerve entrapment neuropathy), where multiple organs are involved, can be observed $(1,4)$. In patients who are suspected of having MPS based on clinical findings, firstly urinary GAG measurement is performed followed by specific lysosomal enzyme activity in leukocytes for definitive diagnosis (5).

Today, enzyme replacement therapy (ERT) and hematopoietic stem cell transplantation are used as therapeutic choices in MPS (6-9). However, as is the case with all other degenerative diseases, early diagnosis and onset of treatment prior to the occurrence of permanent injuries is of great significance with respect to treatment response (10). In this study, we present the demographic and clinical features of 27 MPS patients who were diagnosed, treated, and followed up at our hospital.

\section{Materials and Methods}

Twenty-seven MPS patients who were diagnosed at Dokuz Eylül University, Department of Pediatric Metabolism and Nutrition were included in our study. Demographics, blood relation between parents, clinical and imaging findings, time of diagnosis and monitoring, ERT treatment, age and cause of death were retrospectively investigated. The diagnosis of MPS was established based on clinical and imaging findings, urinary GAG assay, specific enzyme level measurement and genetic mutation assay.

\section{Statistical Analysis}

Data analysis was performed using the software, "SPSS for Windows 22". Descriptive statistics were expressed as mean \pm standard deviation or median (minimum-maximum) for discontinuous numeric variables, and categorical variables were expressed as case number and (\%).

\section{Results}

The mean age of the patients was $112.3 \pm 52.5$ months (36-196 months), the mean age of symptom onset was $40.8 \pm 30.6$ months (4-112 months), the age of diagnosis was $57.7 \pm 39.0$ months (6-112 months), and the mean duration from symptom onset to diagnosis was $16.3 \pm 21.4$ months (0-80 months). There were 10 females (37\%) and 17 males (63\%). Thirteen patients (48\%) were diagnosed with MPS Type III, seven (26\%) with Type II, four (15\%) with Type VI, two (7\%) with Type I, and one patient (4\%) with MPS Type IV.

There was consanguinity between parents in 13 (48\%) patients. Ten patients (37\%) had history of sibling death, MPS findings were detected in the relatives or siblings of eight (29\%) patients. Twenty-five patients (96.3\%) had typical face, and 18 had (66.7\%) hepatosplenomegaly (Figure 1). Echocardiographic investigation revealed 16 patients (59.3\%) with cardiac involvement (mitral failure, mitral stenosis, tricuspid failure, aortic failure, aortic stenosis, interventricular septal hypertrophy, left ventricular hypertrophy) (Figure 1). There were eight patients $(29.6 \%)$ with corneal opacity. Nineteen patients (74.1\%) were detected to have dysostosis multiplex on bone imaging (Figure 1). Nine patients (33\%) were operated on due to inguinal/umbilical hernia, adenoid vegetation, and hip dysplasia.

ERT was started on nine patients (33.3\%), and all patients except one received regular treatment. The mean duration of ERT was $31.3 \pm 21.5$ months (9-67 months). One patient was detected to have an allergic reaction during ERT. All patients were given a physical therapy programme for the treatment of their joint contractures. Two patients died during follow-up; the cause of death was respiratory failure and infection (sepsis).

\section{Discussion}

In this study, we retrospectively investigated the demographic and clinical features of MPS patients who were followed up at our hospital. The majority of the patients in our study consisted of MPS Type III (48\%) and MPS Type II (26\%) cases. Reviewing the European studies, we saw that MPS Type III and MPS Type I (11) in Germany, MPS Type III and MPS Type I (12) in Switzerland and MPS Type III and MPS Type II (13) were the most commonly detected types.

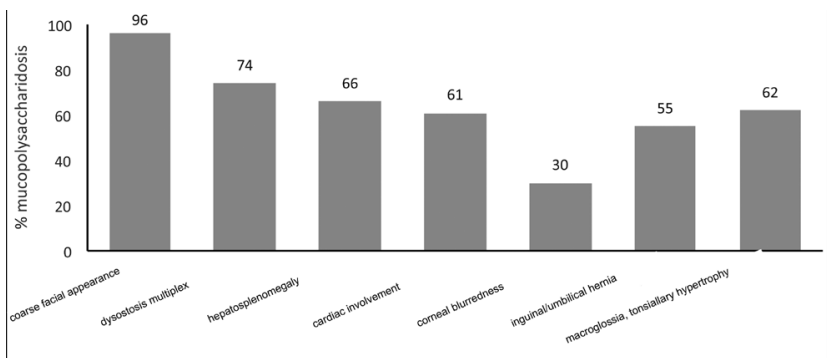

Figure 1. Clinical features of cases with mucopolysaccharidosis 
Reviewing different geographic regions showed us that MPS III and MPS I were detected frequently in Tunisia (14) while MPS VI was relatively more common in Egypt, different from the other countries (15). Australian studies revealed MPS III and MPS I (16) as the most common types; and MPS II was the most common type in the Philippines (17). As for the studies in our country, the most common types of MPS detected by several authors (18) are as follows: Koca et al. (18) detected MPS Type III and MPS Type I in 42 MPS patients; KIlıç et al. (19) detected Type III and Type IV in 177 patients, and Kara et al. detected Type VI and Type IV in 61 patients (Kara A. Evaluation of diagnosis, clinical and laboratory parameters and follow-up findings of inborn errors of metabolism patients who get diagnosed or followed up in Çukurova University Medical Faculty, Pediatric Metabolism Unit. Çukurova University, unpublished doctoral dissertation, Adana. 2012). In our study, $48 \%$ of our patients had consanguinity between parents. Other studies from Turkey report this rate as between 82 and $91 \%(18,20)$.

Our patients applied to us most frequently with complaints of growth retardation and bone deformities. Physical examination findings showed that the most commonly detected clinical findings were coarse facial appearance, skeletal findings, and hepatosplenomegaly. In the literature, published demographic studies involving different types of MPS reveal the most common clinical findings as follows: coarse face, corneal opacity, macroglossia in MPS I (21); short stature, joint stiffness, and coarse facial appearance in MPS II (17); growth retardation, coarse face, hepatosplenomegaly in MPS III (22); short stature, limited joint movement, pectus carinatum in MPS IV (23); coarse face, joint and skeletal abnormalities in MPS VI (24). In our study, since the number of patients with subtypes of MPS was limited, no differentiation based on subtype could be made.

In this disease group, for which early diagnosis and early treatment onset are important in determining the prognosis, mean duration from symptom onset to diagnosis was 16.3 months in our study. Similar to ours, several studies from different countries showed that the diagnosis was established on average 2-3 years after the onset of symptoms (20,25-29). In a case of MPS, since patients exhibit different organ/system manifestations, they present to physicians from different branches including pediatricians, geneticists, cardiologists, ophthalmologists, orthopedists, and neurosurgery, and are diagnosed with different disorders such as primary valvular heart disease, Perthes disease, congenital talipes equinovarus, spondyloepiphyseal dysplasia, cataract, rheumatoid arthritis, craniosynostosis, pseudoachondroplasia, and inguinal hernia $(23,27,29,30)$. In a study, patients were detected to be evaluated by 5 physicians on average before the diagnosis was made (29). Many studies involving different MPS types have demonstrated that early onset of ERT has many benefits including reduction of cardiac hypertrophy, slowing down somatic findings, and increasing quality of life (31-34). Therefore, it is very important to increase awareness of the disease among physicians from different branches so that the patients can be diagnosed as early as possible and treatment initiated in the early stage.

\section{Study Limitations}

This study has some limitations. Firstly, the sample size of the group was small. We could not make the subgroup comparisons of different MPS types regarding main complaints, clinical findings and prognosis. Secondly, we did not perform mutation analysis of all the patients in this study. Last limitation was the relative short follow-up duration of the patients.

\section{Conclusion}

In our study, we detected that MPS patients were diagnosed 16 months after the onset of symptoms on average, and the ratio of consanguinity between parents was $48 \%$. Early diagnosis and treatment are important for the prognosis in MPS. Training practitioners, pediatricians, cardiologists, rheumatologists, radiologists, and specialists of other branches involved in the treatment of MPS, and increasing awareness of the slow-progressing symptoms would contribute to the early diagnosis and treatment of MPS.

\section{Ethics}

Ethics Committee Approval: Retrospective study. Informed Consent: Retrospective study.

Peer-review: External and internal peer-reviewed.

\section{Authorship Contributions}

Surgical and Medical Practices: P.T.K., E.K., Concept: N.A., P.T.K., Design: N.A., Data Collection or Processing: E.K., M.A., P.T.K., Analysis or Interpretation: E.K., M.A., Literature Search: P.T.K., Writing: N.A., P.T.K.

Conflict of Interest: No conflict of interest was declared by the authors.

Financial Disclosure: The authors declared that this study received no financial support.

\section{References}

1. Wraith JE, Beck M, Lane R, et al. Enzyme replacement therapy in patients who have mucopolysaccharidosis I and are younger than 5 years: results of a multinational study of recombinant human alpha-L-iduronidase (laronidase). Pediatrics 2007;120:37-46.

2. Beck M, Arn P, Giugliani R, et al. The natural history of MPS I: global perspectives from the MPS I Registry. Genet Med 2014;16:759-65

3. Muenzer J. Overview of the mucopolysaccharidoses. Rheumatology 2011;50:4-12. 
4. Cimaz R, La Torre F. Mucopolysaccharidoses. Curr Rheumatol Rep 2014;16:389.

5. Andrade F, Aldámiz-Echevarría L, Llarena M, Couce ML. Sanfilippo syndrome: Overall review. Pediatr Int 2015;57:331-8.

6. Jameson E, Jones $\mathrm{S}$, Remmington T. Enzyme replacement therapy with laronidase (Aldurazyme ${ }^{\circledR}$ ) for treating mucopolysaccharidosis type I. Cochrane Database Syst Rev 2016;4:CD009354.

7. Kunin-Batson AS, Shapiro EG, Rudser $K D$, et al. Longterm cognitive and functional outcomes in children with mucopolysaccharidosis (MPS)-IH (Hurler Syndrome) treated with hematopoietic cell transplantation. JIMD Rep 2016;29:95-102.

8. Brunelli MJ, Atallah ÁN, da Silva EM. Enzyme replacement therapy with galsulfase for mucopolysaccharidosis type VI. Cochrane Database Syst Rev 2016;3:CD009806.

9. da Silva EM, Strufaldi MW, Andriolo RB, Silva LA. Enzyme replacement therapy with idursulfase for mucopolysaccharidosis type II (Hunter syndrome). Cochrane Database Syst Rev 2016;2:CD008185.

10. Gabrielli O, Clarke LA, Ficcadenti A, et al. 12 year follow up of enzyme-replacement therapy in two siblings with attenuated mucopolysaccharidosis I: the important role of early treatment. BMC Med Genet 2016;17:19

11. Baehner F, Schmiedeskamp C, Krummenauer $F$, et al Cumulative incidence rates of the mucopolysaccharidoses in Germany. J Inherit Metab Dis 2005;28:1011-7.

12. Malm G, Lund AM, Mansson JE, Heiberg A. Mucopolysaccharidoses in the Scandinavian countries: incidence and prevalence. Acta Pædiatrica 2008;97:1577-81.

13. Jurecka A, Ługowska A, Golda A, Czartoryska B, TylkiSzymańska A. Prevalence rates of mucopolysaccharidoses in Poland. J Appl Genet 2015:56;205-10.

14. Ben Turkia $\mathrm{H}$, Tebib N, Azzouz $\mathrm{H}$, et al. Incidence of the mucopolysaccharidoses in Tunisia. Tunis Med 2009;87:782-5.

15. Elmonem MA, Mahmoud IG, Mehaney DA, et al. Lysosoma storage disorders in egyptian children. Indian $\mathrm{J}$ Pediatr 2016;83:805-13.

16. Meikle PJ, Hopwood JJ, Clague AE, Carey WF. Prevalence of lysosomal storage disorders. JAMA 1999;28:249-54.

17. Chiong MA, Canson DM, Abacan MA, Baluyot MM, Cordero CP, Silao CL. Clinical, biochemical and molecular characteristics of Filipino patients with mucopolysaccharidosis type II-Hunter syndrome. Orphanet J Rare Dis 2017;12:7.

18. Koca S, Okur I, Eminoglu TF, ve ark. Gazi Üniversitesi Tıp Fakültesi Çocuk Beslenme ve Metabolizma Bilim Dalı'nda takip edilen mukopolisakkaridozlu hastaların klinik ve laboratuar özellikleri. J LSD 2008;1:81-3.

19. Kılıç M, Kalkanoğlu Sivri SH, Tokatlı A, Dursun A, Coşkun T. Mukopolisakkaridozlar: 3 Yıllık Hacettepe Deneyimi. J LSD 2010;2:83
20. Er E, Canda E, Uçar Kalkan S, Sözmen E, Çoker M. Mukopolisakkaridoz Tip VI (Maroteaux-Lamy Sendromu) tanılı hastalarda klinik deneyim. J Pediatr Res 2016;3:82-5.

21. Giugliani R, Federhen $A$, Rojas $M V$, et al. Mucopolysaccharidosis I, II, and VI: Brief review and guidelines for treatment. Genet Mol Biol 2010;33:589-604.

22. Buhrman D, Thakkar K, Poe M, Escolar ML. Natural history of Sanfilippo syndrome type A. J Inherit Metab Dis 2014;37:431-7.

23. Bhattacharya K, Balasubramaniam S, Choy YS, et al. Overcoming the barriers to diagnosis of Morquio $A$ syndrome. Orphanet J Rare Dis 2014;9:192.

24. Valayannopoulos $V$, Nicely $H$, Harmatz $P$, Turbeville $S$. Mucopolysaccharidosis VI. Orphanet J Rare Dis 2010;5:5.

25. Lin $H Y$, Chuang $C K$, Huang $Y H$, et al. Causes of death and clinical characteristics of 34 patients with Mucopolysaccharidosis II in Taiwan from 1995-2012. Orphanet J Rare Dis 2016;11:85.

26. Sohn YB, Choi EW, Kim SJ, et al. Retrospective analysis of the clinical manifestations and survival of Korean patients with mucopolysaccharidosis type II: emphasis on the cardiovascular complication and mortality cases. Am J Med Genet A 2012;158:90-6.

27. Choy SY, Bhattacharya K, Balasubramaniam S, et al. Identifying the need for a multidisciplinary approach for early recognition of mucopolysaccharidosis VI (MPS VI). Mol Genet Metab 2015;115:41-7.

28. D'Aco K, Underhill $L$, Rangachari $L$, et al. Diagnosis and treatment trends in mucopolysaccharidosis I: findings from the MPS I Registry. Eur J Pediatr 2012;171:911-9.

29. Bruni S, Lavery C, Broomfield A. The diagnostic journey of patients with mucopolysaccharidosis I: A real-world survey of patient and physician experiences. Mol Genet Metab Rep 2016;8:67-73.

30. Morishita K, Petty RE. Musculoskeletal manifestations of mucopolysaccharidoses. Rheumatology (Oxford). 2011;50(Suppl 5):19-25.

31. Lin HY, Chuang CK, Chen MR, et al. Cardiac structure and function and effects of enzyme replacement therapy in patients with mucopolysaccharidoses I, II, IVA and VI. Mol Genet Metab 2016;117:431-7.

32. Cho SY, Lee J, Ko AR, et al. Effect of systemic high dose enzyme replacement therapy on the improvement of CNS defects in a mouse model of mucopolysaccharidosis type II. Orphanet J Rare Dis 2015;10:141.

33. Tajima G, Sakura N, Kosuga M, Okuyama T, Kobayashi $M$. Effects of idursulfase enzyme replacement therapy for Mucopolysaccharidosis type II when started in early infancy: comparison in two siblings. Mol Genet Metab 2013;108:172-7.

34. Franco JF, Soares DC, Torres LC, et al. Short Communication Impact of early enzyme replacement therapy for mucopolysaccharidosis $\mathrm{VI}$ : results of a long-term follow up Brazilian siblings. Genet Mol Res 2016;22:15. 